\title{
Pembaharuan Website MAN 12 Jakarta Sebagai Media Informasi Digital Kepada Mayarakat
}

\author{
Dine Tiara Kusuma ${ }^{1}$; Yessy Fitriani ${ }^{2}$; M. Yoga Distra $S^{3}$ \\ 1,2,3 Institut Teknologi PLN \\ 1.dinetiarakusuma@gmail.com
}

\begin{abstract}
A website is needed for schools to provide information to the public about all activities carried out. MAN 12 Jakarta requires a more interactive and dynamic website update. This is deemed necessary so that users from the admin side can easily update information and be more attractive to readers. Besides that, for schools the website is also one of the evaluation components during the accreditation process. To be able to support these needs, at the occasion of Community Service, the Istitut Teknologi PLN is currently updating the MAN 12 Jakarta website in order to meet the needs of the school and support the existence of schools in the community. The results achieved from this Community Service activity are the formation of a more informative and dynamic website for MAN 12 Jakarta that can be accessed on the page http://man12jkt.sch.id/
\end{abstract}

Keywords: website, MAN 12 Jakarta, Digital Media

\begin{abstract}
ABSTRAK
Website diperlukan bagi sekolah untuk memberikan informasi kepada masyarakat tentang segala kegiatan yang dilaksanakan. MAN 12 Jakarta membutuhkan pembaharuan website yang lebih interaktif dan dinamis. Hal ini dirasa perlu agar pengguna dari sisi admin dapat dengan mudah mengupdate informasi dan dapat lebih menarik untuk para pembaca. Selain itu bagi pihak sekolah website juga merupakan salah satu komponen penilaian saat proses akreditasi. Untuk dapat mendukung kebutuhan tersebut maka pada kesempatan Pengabdian Pada Masyarakat saat ini Institut Teknologi PLN melakukan pembaharuan website MAN 12 Jakarta agar dapat memenuhi kebutuhan pihak sekolah dan mendukung eksistensi sekolah di kalangan masyarakat. Hasil yang di capai dari kegiatan Pengabdian Pada Masyarakat ini adalah terbentuknya sebuah website untuk MAN 12 Jakarta yang lebih informatif dan dinamis yang dapat di akses pada laman http://man12jkt.sch.id/
\end{abstract}

Kata kunci: website, MAN 12 Jakarta, Media Digital 


\section{PENDAHULUAN}

Website sekolah saat ini menjadi tren didunia pendidikan untuk mendapatkan perhatian, tanggapan yang sangat bagus dari berbagai pihak baik itu dari tenaga kependidikan, siswa dan juga masyarakat serta keberadaan website sekolah pada saat ini memang sangat penting.

Pengabdian kepada masyarakat yang akan diaksanakan saat ini bertujuan untuk memperkenalkan MAN 12 Jakarta kepada masyarakat luas melalui media digital. Salah satu media digital yang dapat dimanfatkan sebagai media penyampaian informasi adalah website. Saat ini MAN 12 Jakarta sudah memiliki website untuk media informasi, namun sebuah website yang interaktif dan informatif sangat dibutuhkan agar tidak terlalu kaku dalam segi tampilan maupun penggunaan nya baik dari sisi admin ataupun pembaca dari luar MAN 12 Jakarta.

Oleh karena itu perlu dirancang kembali sebuah website baru yang lebih manarik dan informatif bagi penguna sesuai dengan kebutuhan sekolah, website baru yang akan dirancang tersebut harus dapat memberikan informasi mulai dari struktur organisasi sekolah, visi dan misi, hingga semua kegiatan yang berlangsung di sekolah sehingga pihak dari luar kampus dapat mengetahui semua kegiatan yang berlangsung di sekolah melalui media digital. Untuk dapat mendukung kebutuhan tersebut maka diperlukan pembaharuan website MAN 12 Jakarta agar dapat memenuhi kebutuhan pihak sekolah dan mendukung eksistensi sekolah di kalangan masyarakat.

\section{METODE}

\subsection{Metode Pelaksanaan}

Metode pelaksanaan yang akan digunakan pada P2M ini adalah:

1. Survey ke mitra Madarasah Aliyah Negri 12 Jakarta untuk menggali lebih lanjut kebutuhan (requirement) dari mereka terkait sistem yang sedang berjalan.

2. Merancang bersama mitra Madarasah Aliyah Negri 12 Jakarta program P2M lebih detail sesuai kebutuhan.

3. Melaksanakan P2M sesuai jadwal yang telah disepakati antara tim dan mitra.

4. Melakukan evaluasi hasil pelaksanaan P2M dengan pihak Madarasah Aliyah Negri 12 Jakarta.

Membuat laporan pertanggungjawaban pelaksanaan P2M kepada LPPM Institut Teknologi PLN.

\subsection{Metode Pelatihan}

Metode pelatihan P2M ini adalah :

1. Mengumpulkan informasi mengenai kebutuhan spesifik mitra MAN 12 Jakarta untuk Website utama nya melalui serangkaian percakapan dan diskusi saat proses rancang bangun website ini berlangsung serta dari beberapa pertemuan lainnya dengan pihak-pihak inti MAN 12 Jakarta.

2. Merancang modul dan teknik pelatihan yang sesuai dengan kebutuhan mitra, berdasarkan fitur-fitur yang ada pada aplikasi dan hasil diskusi dengan mitra.

3. Melaksanakan pelatihan sesuai jadwal yang telah disepakati antara tim dan mitra.

4. Pelatihan dilakukan secara Luring dan Daring. Pelatihan secara Luring dilakukan sebelum kondisi pandemi yang terjadi di Indinesia. Namun saat kondisi Pandemi terjadi maka pelatihan dilakukan secara daring melalui aplikasi teams ataupun zoom.

5. Membuat laporan pertanggungjawaban pelaksanaan P2M. 


\section{HASIL DAN PEMBAHASAN}

\subsection{HASIL}

Berikut hasil website MAN 12 Jakarta yang sudah diperbaharui :

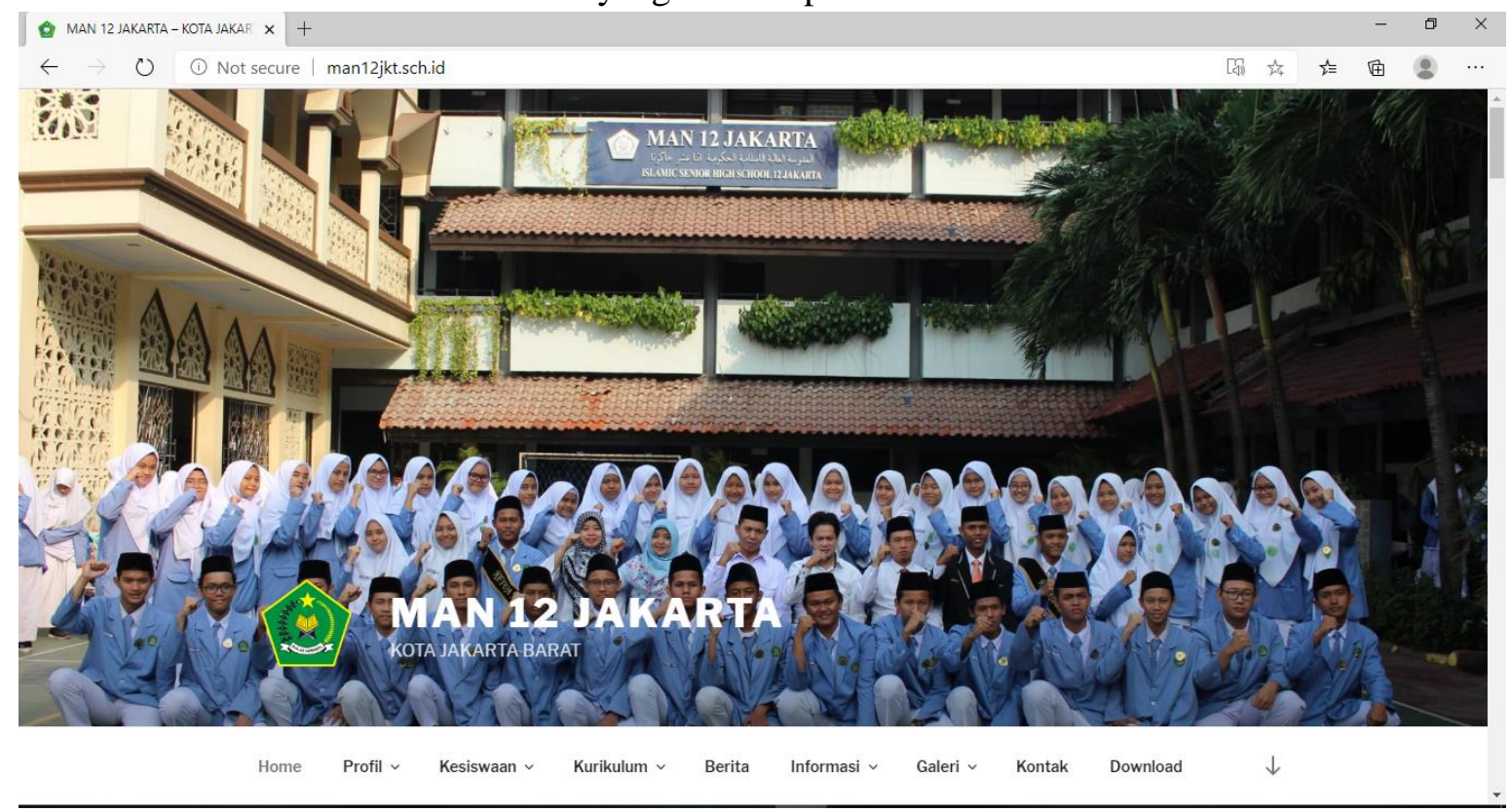

Gambar 1. Tampilan Utama Website

Untuk dapat melihat website tersebut pengguna dapat mengakses ke halaman : http://man12jkt.sch.id/. Hingga laporan ini di sampaikan website tersebut telah di bangun dan telah mencapai tahapan hosting agar dapat di akses oleh pengguna baik admin maupun masyarakat.

1. Menu pada website

Sesuai hasil diskusi yang dilakukan dari tim P2M Institut Teknologi PLN dan pihak MAN 12 Jakarta, maka diperoleh kesepakatan bahwa dalam pembaharuan website ini terdapat 9 menu di dalam nya. Menu tersebut antara lain:

a. Home

Home merupakan halaman utama yang tampil saat pertama kali pengguna menagakses halaman web.

b. Profil

Halaman profil adalah halaman yang berisi gambaran umum tentang MAN 12 Jakarta, mulai dari Sejarah, Visi dan Misi, serta Struktur Organisasi

c. Kesiswaan

Kesiswaan adalah halaman yang berisi tentang berita kegiatan yang dilakukan oleh siswa MAN 12 Jakarta baik dari kegiatan Osis hingga kegiatan ekstra Kurikuler.

d. Kurikulum

Kurikulum adalah halaman yang menggambarkan tentang Pendidik, Tenaga Kependidikan serta Agenda Kurikulum dari MAN 12 Jakarta

e. Berita

Berita adalah halaman yang menampilkan segala bentuk berita dan informasi yang di posting oleh admin sekolah.

f. Informasi

Informasi adalah halaman yang berisi tentang segala bentuk informasi yang dapat di sampaikan kepada siswa maupun pembaca lainnya seperti Beasiswa dan lain sebagainya. 
g. Galeri

Galeri adalah halaman yang berisi foto-foto dan video tentang segala kegiatan yang berlangusng di MAN 12 Jakarta

h. Kontak

Kontak adalah halaman yang berisi informasi alamat dan petunjuk MAN 12 Jakarta

i. Download

Download adalah menu yang berisi dokumen-dokumen yang dapat di unduh oleh pengguna.

\subsection{PEMBAHASAN}

Dalam pembaharuan website MAN 12 Jakarta memerlukan masukan - masukan dari pengguna. Masukan - masukan tersebut antara lain :

1. Tampilan yang dinamis

2. Mudah di akses

3. Admin dapat dengan mudah posting berita

4. Diadakan nya pelatihan untuk admin dalam menulis berita

5. Tampilan yang menarik

6. Proses hosting yang mudah dan sesuai kebutuhan.

Dari beberapa poin di atas maka proses pembaharuan ersebut dilakukan dalam beberapa tahapan yakni :

Langkah 1 : Melakukan perancangan terhadap Website MAN 12 Jakarta sesuai dengan kebutuhan dari pihak MAN 12 Jakarta

Langkah 2 : Setelah hasil rancangan telah sesuai dan disepakati bersama, langkah selanjutnya adalah melakukan pelatihan kepada para administrator MAN 12 dalam penggunaan website MAN 12 Jakarta yang telah diperbaharui

Langkah 3 : Melakukan diskusi lebih lanjut dengan kepala sekolah dan Administrator TI tentang kebutuhan peserta pelatihan sebelumnya untuk penyempurnaan website

Langkah 4 : Melakukan penyempurnaan terhadap menu yang tersidia sesui kebutuhan

Langkah 5 : Melakukan diskusi tentang kebutuhan hosting website, kapasitas media penyipanan yang dibutuhkan serta harga yang dapat di bayarkan untuk hosting dan sewa media penyimpanan cloud

Langkah 6 : Setelah disepakati proses pada langkah 5 maka Tim P2M Institut Teknologi PLN melakukan proses hosting website tersebut

Langkah 7 : Melakukan pelatihan jurnalistik kepada siswa, guru dan admin pengelola website agar dapat mengupdate berita dan informasi website secara periodik.

Langkah 8 : Memastikan website telah terhosting dengan baik

\section{KESIMPULAN DAN SARAN}

\subsection{Kesimpulan}

Berdasarkan hasil dari kegiatan Pengabdian kepada masyarakat yang telah dilakukan maka kesimpulan yang dapat diperoleh adalah:

1. Setelah dilakukan diskusi tentang kebutuhan sistem secara luring maupun daring kepada pihak MAN 12 Jakarta, maka disepakati pembaharuan website MAN 12 Jakarta dilakukan oleh tim P2M dari Institut Teknologi PLN

2. Tim P2M Institut Teknologi PLN memberikan pelatihan penggunaan website baik dari untuk admin berita ataupun admin yang bertanggung jawab merawat website ini. 
3. Selama masa P2M ini berlangsung tim P2M dari Institut Teknologi PLN akan terus medampingi MAN 12 Jakarta baik dari cara penggunaan hingga maintenance website.

\subsection{Saran}

Berdasarkan kegiatan yang telah dilakukan saran yang dapat disampaikan pada kegiatan P2M kali ini adalah agar dapat dilakukan majemen waktu untuk kegiatan pelatihan secara daring. Mengingat keadaan yang terjadi saat ini tidak memungkinkan untuk dilakukan pelatihan secara luring.

\section{UCAPAN TERIMAKASIH}

Pada kesempatan ini ucapan terimakasih yang sebesar-besarnya disampaikan kepada Institut Teknologi PLN atas segala bentuk dukungan nya agar penelitian ini dapat berjalan dengan sebaikbaiknya.

\section{DAFTAR PUSTAKA}

[1] Bin Ladjamudin, Al Bahra "Analisis dan Desain Sistem Informasi” oleh Penerbit Graha Ilmu, Tangerang 2005.

[2] Bunafit, Nugroho, “Aplikasi Pemrograman”, Gava Media, Yogyakarta 2004.

[3] Christian, Andi, "JURNAL SISFOKOM Vol 7 Nomor 1", 2018

[4] Fathansyah, Ir "Basis Data" oleh Penerbit Informatika, Bandung 2004.

[5] Jogiyanto, Hartono, “Analisis \& Desain” oleh Penerbit Andi, Yogyakarta, 2005.

[6] Kadir, Abdul, "Pengenalan Sistem Informasi", oleh Penerbit Andi Yogyakarta, Yogyakarta 2003.

[7] Kristanto, Andri "Perancangan Sistem Informasi Dan Aplikasinya" oleh Penerbit Gava Media, Klaten 2008. 